\title{
Social Stigma- A Hindrance of Social Health and Social Rehabilitation of Female Sex Workers
}

\author{
Harasankar Adhikari ${ }^{1 *}$ \\ ${ }^{1}$ Calcutta based independent social worker, INDIA \\ *Corresponding Author: jaoya123@yahoo.co.in
}

Citation: Adhikari, H. (2016) Social Stigma- A Hindrance of Social Health and Social Rehabilitation of Female Sex Workers, European Journal of Sociology and Anthropology, 1:2 (2016), 3. doi:10.20897/ejsa.201603

Received: August 9, 2016; Accepted: December 15, 2016; Published: December 25, 2016

\begin{abstract}
This paper examines the self-strategies of female sex workers (FSWs) for their integration into the larger society from the stigma of sex workers and it also explores how they were neglected by larger society. The study was conducted in the Bowbazar red-light area of Kolkata. For this purpose, 110 Female Sex Workers (FSWs) were purposively selected through adopting simple random sampling. Before that the researcher conducted a survey to know their future goals, where the FSWs shared their goal to withdraw from the trade after a certain age. The information collected was on their social, religious, and educational backgrounds; marital status and relationships with male partners; and social and economic strategies for their rehabilitation. Methodologies included interview schedules, case studies, and regular interaction for a period of 10 years. The study revealed that 7\% of the FSWs integrated themselves within the larger society after their withdrawal from the trade. While about $60 \%$ of them targeted to withdraw from this trade. The stigma attached to this profession was a prime hindrance of their social rehabilitation and thus a portion of them faced violence and returned to their sex workers' communities after withdrawal from the trade. The struggle for the improvement of their social health was the prime target to restore their future well-being of our society.
\end{abstract}

Keywords: female sex workers, social and economic rehabilitation, social health, male partners

\section{INTRODUCTION}

Physical, mental and social health determines together individual's health. However, social health is less intuitively concerned than that of physical or mental health. "A society is healthy when there is equal opportunity for all and access by all to the goods and services essential to full functioning as a citizen." (Sarkin, et. al, 2011, pp 454-462). Indicators of the health of a society include the existence of the rule of law, equality in the distribution of wealth, public accessibility of the decision-making process, and the level of social capital (Thomas, 2015). The social health of individuals refers to that dimension of an individual's well-being that concerns how he/she gets along with other people, how other people react to him, and how he interacts with social institutions and societal mores (Sarkin, et. al, 2011, pp 454-462). In fact, it incorporates elements of personality and social skills. From this, we could learn the social norms of a particular society where we born and brought up, and finally, it bears a close relationship to concepts such as "well-being," "adjustment," and performing of "social functions" i.e. social and cultural rituals. In 1947, World Health Organization (WHO) included social health as a parameter of health. It advised that a patient would be considered as a social being during his/her treatment aiming to integrate him/her with the community. It would be the best policy for faster recovery of a patient from his/her disease. On the other hand, social isolation might be a risk factor for prolonged illness. Hence, social health may be defined either in terms of social adjustment and social support or the ability to execute the societal roles. It also improves the collective values of the social network as an important input of social capital (Thomas, 2015). Secondly, it is a 
mutual trust and reciprocity in a community, as an important indicator of social health (Hawe \& Shiell, 2000, pp 871-885).

Particularly in the Indian context, the issue of the social health of its citizens almost ignores, other than some schemes for poor groups suffering from social isolation and several social, cultural, and economical disparities or backwardness. In this paper, researcher concentrated on prostitution, one of the oldest professions (Tomura, 2009, pp 51-84) and a multi-billion-dollar industry employing millions of women world-wide because in this trade, women are the ultimate entrepreneurs whose products never get out of style, and they are socially isolated and stigmatized. The social stigmatization of sex workers is deep-rooted negatively affects their well-being (Bradley, 2007, pp 379-406; Jackson, Bennett, \& Sowinski, 2007, pp 275-271; Kong, 2006, pp 409-434; Thomson, Harred, \& Burks, 2003, pp 551-571; Vanwesenbeeck, 2005, pp 627-639). That's why; they generally hide their identity to avoid being labeled negatively. It causes stress, anxiety and exhaustion in their living (Tomura, 2009). 'This stigma continues to surround the plausibility of sexual labour as a commodity and dominates current perceptions and societal unease' (Howe, 2014, pp 14-71). However, there is no concrete initiative taken for their social rehabilitation so far. Commercial sex work has three main categories which are influenced by the status of women. At the toplevel is the indoor or housed activity, which is mainly for top class prostitutes. The escort agencies and call girls are under this category. The low profile female sex workers are brothel based sex workers. But commercial sex work has its own professional dangers and challenges due to its nature of services. Further, it depends on varied socioeconomic and political system of the society. The most significant challenge lies in the social system which attached stigma and discrimination to the sex entrepreneurs. Hubbard and Sanders (2003) argue that female prostitutes suffer from social discrimination, violence, and intolerance. They note that the general populace attaches five stereotyping descriptions that lead to prostitute being deemed to be social maladjustment. The five descriptions entail that "prostitutes smell bad, prostitutes are socially dead, prostitutes are diseased, prostitutes are a submissive sex object, and prostitutes are a necessary outlet for natural male excess." The HIV and AIDS pandemic is a challenge to the commercial sex workers because their clients are intermediately group. In some cases, the clients pay higher for unprotected sex. Most prostitutes are then infected because of the profit motive. This one-dimensional approach to the cause of prostitution has been used to frame the debates around whether prostitution should be legalized without enough or equal scrutiny being placed on the men who facilitate the continued existence of the sex work, trade and the men who make it profitable for women to trade their bodies (Edlund \& Korn, 2002).

There have many studies conducted by the researchers and these studies are mainly on the political, legal, and economic aspects of commercial sex work. The social aspects are not sincerely covered. Lesley (2000) focused on training women in political leadership. Haleh (2003) looked at women in conflict. Atienza (2000) focused on gender and local governance. Sensitive and contemporary women's plight issues are general discussion of the journalists. Newspapers make a meal out of hearsay and isolated cases, and very few, if any, among the journalists have sought to carry out a scientific inquiry into the urban street prostitution. Women activists are always clamoring for improvement on the legality and equity issues. They want specific and certain aspects addressed as emanating from the challenges women face at law. Mukhopadhyay (2004) noted that in long periods of history, women have been denied of their rights and privileges. The social activists and non-governmental organizations (NGOs) are more concerned about economical rehabilitation of these women. But the most important aspect of social rehabilitation of commercial sex workers is avoided or left far behind or unfocused. There is negligence for the restoration of the social health of these women. It was observed that a significant portion of commercial sex workers had tried to withdraw from the trade after certain years in the trade with their lover/husband outside their community. But they were harassed and were also afraid to get tortured/insulted by the mainstream society.

So, this paper examines how stigma acts as a hindrance of social rehabilitation of sex workers in spite of their self-initiative. And it also analyzes the impact and significance of alternative livelihood for their social and economical rehabilitation.

\section{METHODS}

\section{Universe of the study}

The Bowbazar, a century-long red-light area (out of eight red-light area) of Kolkata (only metro city in eastern India) was selected for this study because here the female sex workers (FSWs) had been settled in their households with their paramour/husband and children (sometime siblings or relatives also). The community as well as their family had a typical structure and process. The history of this brothel reminded that a relative of Prince Dwarakanath Tagore (grandfather of Poet Rabindranath Tagore owned two houses-355 and 356, in the Bowbazar Street of this area to operate the brothel) (Adhikari, 2007). This old brothel was located in the central part under ward no-48 of the Kolkata Municipal Corporation under jurisdiction of Muchipara Police Station. A 
Table 1. Causes responsible for drawing women into the trade by religion and age (in years) \& marital status at the time of entering into the trade

\begin{tabular}{|c|c|c|c|c|c|c|c|c|c|}
\hline \multirow[b]{4}{*}{$\begin{array}{l}\text { Reason for entry } \\
\text { into the trade }\end{array}$} & \multicolumn{8}{|c|}{ Religion } & \multirow[b]{4}{*}{ Total } \\
\hline & \multicolumn{4}{|c|}{ Hindu } & \multicolumn{4}{|c|}{ Muslim } & \\
\hline & \multicolumn{2}{|c|}{ Below 18 years } & \multicolumn{2}{|c|}{ Above 18 years } & \multicolumn{2}{|c|}{ Below 18 years } & \multicolumn{2}{|c|}{ Above 18 years } & \\
\hline & $\begin{array}{c}\text { Unmarried } \\
(\mathrm{n}, \%)\end{array}$ & $\begin{array}{c}\text { Married } \\
(\mathrm{n}, \%)\end{array}$ & $\begin{array}{c}\text { Unmarried } \\
(\mathrm{n}, \%)\end{array}$ & $\begin{array}{c}\text { Married } \\
(\mathrm{n}, \%)\end{array}$ & $\begin{array}{c}\text { Unmarried } \\
(\mathrm{n}, \%)\end{array}$ & $\begin{array}{c}\text { Married } \\
(\mathrm{n}, \%)\end{array}$ & $\begin{array}{c}\text { Unmarried } \\
(\mathrm{n}, \%)\end{array}$ & $\begin{array}{c}\text { Married } \\
(\mathrm{n}, \%)\end{array}$ & \\
\hline Acute poverty & $\begin{array}{l}10 \\
(9)\end{array}$ & $\begin{array}{c}7 \\
(6.3) \\
\end{array}$ & $\begin{array}{c}4 \\
(3.6)\end{array}$ & $\begin{array}{c}8 \\
(7.2) \\
\end{array}$ & $\begin{array}{c}7 \\
(6.3) \\
\end{array}$ & $\begin{array}{c}9 \\
(8.1)\end{array}$ & - & $\begin{array}{l}10 \\
(9)\end{array}$ & $\begin{array}{c}55 \\
(50)\end{array}$ \\
\hline $\begin{array}{l}\text { Tortured } \\
\text { committed by } \\
\text { parents/husband }\end{array}$ & - & $\begin{array}{c}4 \\
(3.6)\end{array}$ & - & $\begin{array}{c}4 \\
(3.6)\end{array}$ & $\begin{array}{c}3 \\
(2.7)\end{array}$ & $\begin{array}{c}6 \\
(5.4)\end{array}$ & - & $\begin{array}{c}4 \\
(3.6)\end{array}$ & $\begin{array}{c}21 \\
(19)\end{array}$ \\
\hline Victim of love & $\begin{array}{c}8 \\
(7.2) \\
\end{array}$ & $\begin{array}{c}2 \\
(1.8) \\
\end{array}$ & $\begin{array}{c}4 \\
(3.6) \\
\end{array}$ & - & $\begin{array}{c}3 \\
(2.7) \\
\end{array}$ & $\begin{array}{c}2 \\
(1.8)\end{array}$ & $\begin{array}{c}1 \\
(0.9) \\
\end{array}$ & - & $\begin{array}{c}20 \\
(18)\end{array}$ \\
\hline Broken family & - & - & - & - & $\begin{array}{c}4 \\
(3.6) \\
\end{array}$ & - & - & - & $\begin{array}{c}4 \\
(3.6)\end{array}$ \\
\hline $\begin{array}{l}\text { Up-bringing } \\
\text { process in brothel } \\
\text { community }\end{array}$ & $\begin{array}{c}1 \\
(0.9)\end{array}$ & $\begin{array}{c}1 \\
(0.9)\end{array}$ & $\begin{array}{c}1 \\
(0.9)\end{array}$ & $\begin{array}{c}2 \\
(1.8)\end{array}$ & $\begin{array}{c}2 \\
(1.8)\end{array}$ & $\begin{array}{c}1 \\
(0.9)\end{array}$ & $\begin{array}{c}1 \\
(0.9)\end{array}$ & $\begin{array}{c}1 \\
(0.9)\end{array}$ & $\begin{array}{l}10 \\
(9)\end{array}$ \\
\hline Total & $\begin{array}{c}19 \\
(17.2)\end{array}$ & $\begin{array}{c}14 \\
(12.7)\end{array}$ & $\begin{array}{c}9 \\
(8.1)\end{array}$ & $\begin{array}{c}14 \\
12.7) \\
\end{array}$ & $\begin{array}{c}19 \\
(17.2)\end{array}$ & $\begin{array}{c}18 \\
(16.3)\end{array}$ & $\begin{array}{c}2 \\
(1.8)\end{array}$ & $\begin{array}{c}15 \\
(13.5)\end{array}$ & $\begin{array}{c}110 \\
(100)\end{array}$ \\
\hline
\end{tabular}

Source: Field Work

survey was conducted, and from where it was estimated that approximately 2,200 female commercial sex workers of varied age groups (from below 18 years to above 60 years of age) were operating the sex trade, and they had settled themselves with their family members (lover with whom they tied up emotionally, husband and children).

\section{Participants}

For this study, $110(5 \%$ of 2200 FCSWs) female commercial sex workers between the ages of 35 years and above were selected because during the informal interview and group interaction, they were asked about their future goal with respect to withdrawal from the trade. Among them, a sizable percentage (more than $50 \%$ ) targeted to withdraw after 35 years of age, and that they would settle with their family outside their community.

\section{Research tools/materials used}

The researcher collected data through informal interview and group interaction with the FSWs. The qualitative and quantitative data were collected regarding their demographic profile, i.e. socio-religious background, age of entry \& causes of entry into the trade, and their marital status at time of entering into the trade, etc and their selfstrategy of their social and economic rehabilitation and what was their obstacle to reach their desired target of social rehabilitation for a period of 10 years. In this connection he ran remedial coaching centre for their children for a rapport. Cases relating to their self initiative for social integration were recorded. These cases were transcribed in the discussion section of this paper.

\section{RESULTS}

\section{Demographic background of the informants (FSWs)}

In this study, the FSWs were of different socio-religious backgrounds. Their age of entering into this trade was also varied. There were varied reasons of entry into the trade what we found in this study. The study revealed (Table 1) that half of the informants (FSWs) $(50 \%)$ were in this trade due to poverty and $30 \%$ of them were below 18 years of age at their time of entry into the trade. Of them, 15.3\% FSWs were from the Hindu religious group and $14.4 \%$ of them were Muslim. Their marital status at their time of entry into the trade revealed that $34.4 \%$ of them were of underage marriage. Hindu and Muslim population was equal in percentage. Second largest groups of these FSWS $(20 \%)$ were due to the false sense of security by their paramour lured them into the trade. Of them, $12.6 \%$ FSWs were from Hindu and 5.4\% of them were from Muslim community. Nineteen percent (19\%) were in the trade due to torture committed by their husband and in-laws and it was equal for both Hindu and Muslim. The cultural milieu of the sex workers' community had pushed $10(9 \%)$ girls into the trade. And 4 girls (3.6\%) were due to their broken family and all of them were from Muslim community.

Table 2 described the educational status of the FSWs in respect of their social and religious background. Data showed that out of $32.7 \%$ FSWs who entered into the trade below 18 years, $2.7 \%$ of them were married Hindu. But $14.4 \%$ of them were married Muslim. And among them, 7.2\% FSWs belonged to SCs and OBCs. The FSWs $(15.4 \%)$ of below 18 years of age were unmarried at the time of entry into the trade and $6.3 \%$ of them belonged 
Table 2. Socio-religious and educational status according to their age of entry to the trade

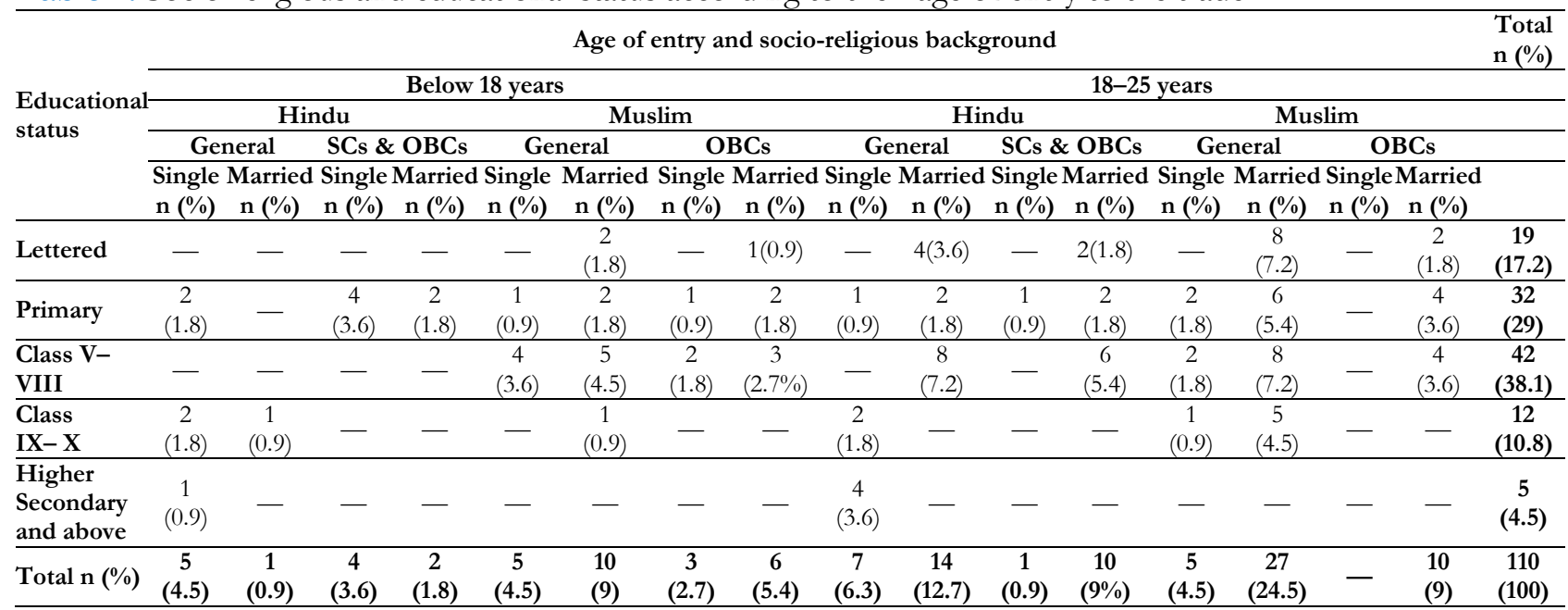

SCs: Scheduled Castes: OBCs: Other backward classes - a new social backward class of people of India who were identified by Mondal Commision, 1990 of India and they were entitled constitutionally to avail reservation in education, employment and other government facilities like SCs.

Source: Field Work

Table 3. Number of children in their family

\begin{tabular}{|c|c|c|c|c|c|c|c|c|}
\hline \multirow{3}{*}{$\begin{array}{l}\text { Age at the } \\
\text { entry to the } \\
\text { trade }\end{array}$} & \multicolumn{8}{|c|}{ Number of children } \\
\hline & \multicolumn{3}{|c|}{$\begin{array}{l}\text { Number of children having with FSWs } \\
\text { at the time entry }\end{array}$} & & \multicolumn{3}{|c|}{$\begin{array}{l}\text { Number of children born after their } \\
\text { entry }\end{array}$} & \multirow[b]{2}{*}{ Total } \\
\hline & $\begin{array}{l}\text { None } \\
\mathrm{n}(\%)\end{array}$ & $\begin{array}{l}\text { Single } \\
\mathrm{n}(\%)\end{array}$ & $\begin{array}{l}\text { Two or more } \\
\text { n }(\%)\end{array}$ & Total & $\begin{array}{l}\text { None } \\
\text { n (\%) }\end{array}$ & $\begin{array}{l}\text { Single } \\
\mathrm{n}(\%)\end{array}$ & $\begin{array}{l}\text { Two or more } \\
n(\%)\end{array}$ & \\
\hline $\begin{array}{l}\text { Below } 18 \\
\text { years }\end{array}$ & $\begin{array}{c}17 \\
(15.4)\end{array}$ & $\begin{array}{c}12 \\
(10.9)\end{array}$ & $\begin{array}{c}7 \\
(6.3)\end{array}$ & $\begin{array}{c}36 \\
(32.7)\end{array}$ & $\begin{array}{c}6 \\
(5.4)\end{array}$ & $\begin{array}{c}20 \\
(18.1)\end{array}$ & $\begin{array}{l}10 \\
(9)\end{array}$ & $\begin{array}{c}36 \\
(32.7)\end{array}$ \\
\hline $18-25$ years & $\begin{array}{c}13 \\
(11.8)\end{array}$ & $\begin{array}{c}40 \\
(36.3)\end{array}$ & $\begin{array}{c}21 \\
(19)\end{array}$ & $\begin{array}{c}74 \\
(67.3)\end{array}$ & $\begin{array}{c}14 \\
(12.7)\end{array}$ & $\begin{array}{c}48 \\
(43.6)\end{array}$ & $\begin{array}{c}12 \\
(10.9)\end{array}$ & $\begin{array}{c}74 \\
(67.3)\end{array}$ \\
\hline $\begin{array}{l}\text { Total } \\
\text { n }(\%)\end{array}$ & $\begin{array}{c}30 \\
(27.2)\end{array}$ & $\begin{array}{c}52 \\
(47.2)\end{array}$ & $\begin{array}{c}28 \\
(25.3)\end{array}$ & $\begin{array}{c}110 \\
(100)\end{array}$ & $\begin{array}{c}20 \\
(18.1)\end{array}$ & $\begin{array}{c}68 \\
(61.7)\end{array}$ & $\begin{array}{c}22 \\
(19.9)\end{array}$ & $\begin{array}{c}110 \\
(100)\end{array}$ \\
\hline
\end{tabular}

Source: Field Work

to SCs and OBCs. Their educational status of this group revealed 7.2\% of these Hindu FSWs attended their primary education and $6.4 \%$ of them attended primary education were of Muslim. $12.7 \%$ of these FSWS attended class VVIII standard of education and all of them were Muslim. Out of 3.6\% FSWs who attended the class IX-X standard, $2.7 \%$ FSWs were Hindu and $0.9 \%$ of them were Muslim. Only $0.9 \%$ of them possess higher secondary and above education and all of them were Hindu.

According to their age the second group $(67.2 \%)$ was within the age of 18-25 years at the time of their entry into the trade. Out of $11.8 \%$ unmarried FSWs, $7.2 \%$ of them were Hindu and $4.5 \%$ FSWs were Muslim. Altogether only $0.9 \%$ FSWs belonged to SCs and OBCs. Educational status stated that 3.6\% of them attended primary education, 1.8\% FSWs (Muslim) attended classes V-VIII standard of education. 2.7\% of them attended the class IX-X standard and 3.6\% of them (of Hindu) possessed higher secondary and above education. Out of $46.3 \%$ FSWs who were married, 21.7\% FSWs were Hindu and the rest of them were Muslim. Among Hindus, 9\% FSWs belonged to SCs and OBCs and an equal percent of them was Muslim. Data showed that among them, 5.4\% FSWs were just lettered of Hindu community and 10.9\% FSWs of same group were from the Muslim Community. Out of $12.7 \%$ FSWs who had primary education, 3.6\% FSWs were Hindu and majority of them (8.1\%) were Muslim. FSWs who attended class V-VIII standard education were $21.8 \%$ and out of them, $12.6 \%$ FSWs were Hindu and $10.8 \%$ FSWs were Muslim. In spite of high school education (class IX-X) of $4.5 \%$ FCSWs belonged to the Muslims community, they pushed into this trade because of their poverty and gender disparity in their community.

\section{Family size of FSWs and relationship with male partner/husband}

In this study, it revealed that all of them (FSWs) had their own household considered by themselves as "line bari" (a family in the brothel). From Table 3, data showed that $72.5 \%$ entered into their trade with their children. $25.3 \%$ FSWs had two or more children. It also revealed that $17.2 \%$ of them joined the trade below 18 years of age with a baby and $6.3 \%$ of them had two or more children. Of them, 36.3\% of FSWs of 18-25 years age entered into the trade with a single baby and 19\% FSWs were then a mother of two or more children. But altogether, 
European Journal of Sociology and Anthropology, 1:2 (2016), 3

Table 4. FSWs' Relationships with male partners/husbands with respect to their age of entry to the trade

\begin{tabular}{|c|c|c|c|c|c|c|}
\hline \multirow[b]{2}{*}{$\begin{array}{l}\text { Age at the } \\
\text { time of entry }\end{array}$} & \multicolumn{5}{|c|}{ Frequency of alteration of male partners } & \multirow[b]{2}{*}{$\begin{array}{l}\text { Total } \\
\mathrm{n}(\%)\end{array}$} \\
\hline & $\begin{array}{l}\text { Never } \\
\mathrm{n}(\%)\end{array}$ & $\begin{array}{l}\text { Once } \\
\text { n ( } \%)\end{array}$ & $\begin{array}{l}\text { Twice } \\
\text { n (\%) }\end{array}$ & $\begin{array}{l}\text { Thrice } \\
\text { n (\%) }\end{array}$ & $\begin{array}{c}\text { More than thrice } \\
n(\%)\end{array}$ & \\
\hline $\begin{array}{l}\text { Below } 18 \\
\text { years }\end{array}$ & $6(5.4)$ & $20(18.1)$ & $4(3.6)$ & $2(1.8)$ & $4(3.6)$ & $36(32.7)$ \\
\hline $18-25$ years & $12(10.9)$ & $25(22.7)$ & $12(10.9)$ & $8(7.2)$ & $17(15.4)$ & $74(67.3)$ \\
\hline $\begin{array}{l}\text { Total } \\
\text { n (\%) }\end{array}$ & 18(16.3) & $45(40.8)$ & $16(14.5)$ & $10(9)$ & 21(19) & $110(100)$ \\
\hline
\end{tabular}

Source: Field Work

$27.2 \%$ of them had no child because they were unmarried at the time of their entry into the trade. Apart from the above scenario, it was also found that $18.1 \%$ FSWs had no child after their entry into the trade and out of which, $12.7 \%$ FSWs were within 18-25 years of age at the time of entry. However, data showed that after entering into the trade, $61.7 \%$ of the FSWs carried single baby and $19.9 \%$ of them were carried two or more children.

Table 4 described the pattern/nature of the relationship of FSWs with a male partner or husband. The researcher also met male partner of FSWs known as "babu" (local known as male partner) during his interview with FSWs. They interacted as a conjugal partner, which might be sanctioned legally or not. But FSWs' relationship with their " $b a b u$ "/husband was in stable and it was also unsettled.

Babu lives as a parasite and he is dependent of FSWs economically. But FSWs' relationship with them rarely brings happiness in their life because they used to torture them often. In fact, FSWs do not bother the fact of torture because they always need a male partner for their social and emotional security and for safe operation of their trade. Beside this negative aspect of their relationship, it is important for their withdrawal from their trade to be discussed later. From Table 4, we get that $16.3 \%$ of them were strictly with one partner and out of which, $10.9 \%$ FSWs who entered into the trade within 18-25 years. But altogether, $40.8 \%$ of them altered their " $b a b u$ " once in their career. About $14.5 \%$ of them altered twice, and $7.2 \%$ of them altered thrice. The data also show that $19 \%$ had altered more than thrice.

\section{Approaches/initiatives towards withdrawal from the trade}

In this study, the interaction with FSWs revealed that they were in the trade due to certain unfortunate circumstances (extreme poverty, gender disparity, and other related causes). But it was their shortcomings in their life. They promised to leave this profession after a certain age (after 35 years) when the sex market would reject them. For withdrawing from the trade and their rehabilitation, they took some initiative alone or jointly with their male partner/husband.

a) Social Aspects of their initiative:

There were obviously professional hazards in the trade. First, it included behavioral practices like consumption of alcohol, and so forth. But about $72 \%$ of them gradually left these practices, and they controlled their behavior. Yet they used to practice hide and seek in their profession when their grown-up children were with them. They used to maintain their dress code which reveals their body to attract customers.

Second, there was a common trend of alteration of male partner $(b a b u)$ in their trade. But after a certain age, they restricted their relationship with one male as their husband, and in that case, their male partner extended their help and support for their withdrawal from trade, and they assisted to settle outside their sex workers' community.

Nevertheless, there was a fashion in this trade that FSWs used to migrate from one red-light area to another due to the pressure of their male partner/babu for their trade prosperity because they think that they would get more scope of earning through getting more customers in a new place after the migration. They also thought that they would get their place at low rent or otherwise. In our study, we find that FSWs (about 60\%) who consigned to withdraw from the trade after reaching a certain age did not follow this fashion of migration. They are habituated to adjust to the place of entry.

b) Economic aspects:

From this study, the researcher observed that these FSWs (about 68\%) had taken an initiative for their economical rehabilitation. For this purpose, they learned to save their earnings in a bank through opening a bank account. The voter identity card and ration card were also with them.

Thereafter, they also used to create their other movable assets like gold ornaments and domestic equipment to settle them outside their community. We find that about $18 \%$ of them had purchased a land not less than 2 kathas $(1,440$ sq. $\mathrm{ft})$ in suburban area of Kolkata for their resettlement after their withdrawal. 


\section{DISCUSSION}

\section{Stigmatized life within communities and outside}

Prostitution is a stigmatized profession undoubtedly and various studies mentioned earlier how the stigma of sex workers affects their well-being and social integration. The women who enter into the trade do not get a chance to take part in larger society. Even their parents or in-laws' family does not accept them, and they usually do not keep relation with them. The stigmatized sex workers' community reshapes their life differently. For their trade they learn particular tactics to attract clients and to build a relationship by which they might be regular visitors to them. The changing behavioral pattern and habits are easily identified when they come outside of their community. This makes them isolated from the larger society. But FSWs, in this study were usually isolated in terms of the behavior and habits. They practiced only the methods to their clients' satisfaction. When they used to visit outside their community; they followed well maintained system secrecy in their identity.

Their target did not always reach a success because their community's influence had an impact. Their community tried to hold them tactically. For instance, brothel owners played a crucial role. They offer loan and other facilities during their crisis. In general, the recovery of this loan is a hard task, so that their future saving gets derided. The male partners/babu who was from the same community abused their emotional state, and they snatched their earnings for their luxurious living. Their relationship was not permanent. This system was unfavorable for their withdrawal. Many times, the local leader of the community who used for liaison with local administration did not extend help and assistance for their civic identity, that is, ration card and voter identity card. As a consequence, they did not avail banking services for their saving habits.

\section{The role of male partner/husband/babu}

Males played various roles in the lives of FSW. The FSWs are pushed by male directly or indirectly into the trade. They play the role of brothel owner. They were client before, and now they acted as babu or husband. The plan for withdrawal from the trade was also associated with a joint venture of both. The males used to help them variously to mainstreaming them into larger society. They always stood by the side of FSWs during their time of crisis. Their identity as husband used to prove safety and security. In this study, male partners of about $40 \% \mathrm{FSWs}$ joined their hands for their rehabilitation outside their trade. They try to settle them in their own natal family as their wives, and they hide their profession. These male partners also arranged proper shelter and support for the children's education and other developmental aspects. Not only their identity as a father, but also their involvement in child care helped to show a light of life outside their community because generally the fatherhood is "costless" and uninvolved in most cases while they were biological father or not.

These males as their husband were collaboratively influenced to set up their household in larger society. In our study, it was recorded that only $7 \%$ of them were thus successful to withdraw from their affiliation to this stigmatized profession.

The Case of Sundari (42) justified the above scenario. Her relationship as well as association with a babu supported her two children's education and her reorganization as second wife. It reshapes her identity for social rehabilitation.

\section{Struggle with the larger society after withdrawal from trade and its consequences}

Their self-plan and strategies were not helping their rehabilitation and mixing with the larger society. Their stigma as sex workers did not leave them when they had physically and mentally left their trade. But they faced torture and violence deliberately by their immediate community where they took shelter.

The case of Rupali (38) was an example of the above fact. According to her statement, she and her marital partner jointly purchased a piece of land 4 kathas at a natal place of her partner in a village, and they arranged their shelter there. But after a few weeks, the local community became aware of their earlier profession and they succeeded to know her involvement in the sex trade. So, they started to taunt them and their children. They socially boycotted them. First, the local community complains against them that they were not suitable to live there. Second, they also indicated that their family would pollute their community. Therefore, they had to leave this place after selling their properties and backed to the Bowbazar.

The case 3 of Nurjahan (45) reminded her settlement with a customer who regularly visited her as her client. She shared the fact of their joint family management system and the process of their social rehabilitation outside their community. She shared that depending on her savings she left the place and started living in a rented house outside their community. They admitted their children in a local school. Her male partner/ husband was a street vendor of vegetable in the suburban market. They were living peacefully. But suddenly, her involvement in sex trade was open to their landlord and it gradually spread over. Therefore, her landlord ordered to vacate that 
place. Her children were harassed by their school mates and teachers. Hence, they left the place and came to their earlier place.

\section{Strategies for economic rehabilitation through alternative livelihood by various out sources (NGOs)}

Various social welfare organizations [non-governmental organizations (NGOs)] including government organizations have taken policies to rehabilitate FSWs economically through alternative livelihood. They arrange skill training in different trades, i.e. needle works, handicrafts, and so forth. Self-help groups were also formed for small savings and introduction of micro-credit policy for their betterment. These are undoubtedly so-called noble initiatives. But these are traditional. These were not participatory planning with beneficiaries. These were just some so-called policy of intervention. It might be claimed by the implementers and policy makers that they were making significant differences in the life of FSWs for their rehabilitation and gradually, FSWs would integrate themselves with the larger society. But there were only publicity and propaganda of their work because none of them rehabilitated and no change occurred in their status.

At first, the life of sex workers shaped as per the need and demands of their profession. At their professional life, they were very much committed to run their trade because it was their survival question. They did not like to waste their time otherwise. Therefore, they only attended these training making the initiator happy. Also, any other alternative employment would not offer nearly equal or more earning than their profession. According to this, they made their schedule of expenses. From any alternative livelihood would not be a supplement or complement of their earnings.

\section{CONCLUSION}

The sex trade is historically a stigmatized profession. Negative labeling and devaluing are prime causes of their social isolation and female sex workers uses for 'managing the sense of stigmatization by persons who know about her prostitution by shifting focus away from devaluing and toward valuable qualities of prostitution; developing occupational esteem and self-esteem through reflection of values' (Tomura, 2009). The women of depressed classes or deserted women get engulfed into the trade for their survival in their retired life. The poverty and gender disparities are very crucial factors of being women in trade. In this study, it is found that women below 18 years and within the age bracket of 18-25 years entered into the trade from various social, religious, and educational backgrounds. Majority of them was pushed into the trade after their marriage. More than $70 \%$ of them entered into the trade with their children. In this trade, they shaped their behavioral pattern as well as habits, according to their occupational needs and demands. It included their relationship with male partners and habits to consume alcohol and other aspects.

The study revealed that a few of them believed that it was their fate for which they were in this profession. But they targeted to withdraw from their trade after a certain age. It was particularly after 35 years of age because it was not suitable for their trade. From this age, the clients/customers do not show interest to involve sexually with them. As result of this, their earning reduces. Before reaching this particular age of rejection in the trade, they silently prepared themselves for their rehabilitation. But only $7 \%$ of them reached their goal where their controlled behavior and male's help (husband's help) along with financial planning were prime factors. But majority of them failed because they had no such commitment and they used to face obstacles in their target. Here, stigma of sex workers was prime hindrance. This situation is a disqualification or a discredit for their social acceptance because the larger society has internalized it as immoral (Goffman, 2004, pp 272). Very surprisingly, only a negligible (7\%) settled themselves outside their community. But the larger society did not accept them due to their attached stigma as a sex worker. They did not get any assistance from any side (even law and other authority). Therefore, they had to return to their community and involved in the trade directly or indirectly. The social health of these FSWs is neglected. There is no need for equal opportunity of wealth. Only the need for equality and status for survival as a human being was not restored according to the largest norms of our society.

The developmental organizations (NGOs) and the government claim that they had extended their hands for the social and economical rehabilitation of FSWs. But in reality, it was a publicity gimmick. The status of FSWs is in the same state. They are stigmatized and their attachment (past or present) are not acceptable to the society.

Various organizations claim to workers' rights and justice to restore their social status as human beings. But how would their social health be. The struggle for strengthening their social health should get first priority for their rehabilitation. Otherwise, the changing scenario does not bring any changes in their life. It reminds us the life of "Noti Binodini-Binodini Dasi", a prostitute-famous theatre actress in the $19^{\text {th }}$ century of Bengal who devoted her whole life to entertain our so-called higher classes. But they did not recognize her talents as actress because she was none other than a prostitute.

A sound and effective policy for their integration into the larger community would be a step for their rehabilitation. Their acceptance in larger society would at least be helpful for survival after their withdrawal from 
this trade. Therefore, we suggest measures and means that may be of good use to the nation. NGOs can also find advocacy space and lobbying lines in their activities.

\section{REFERENCES}

Adhikari, H. (2007). Growing up in Adverse Milieu: Education and Occupation of Sex Workers' Children. Indian Journal of Social Work, 68(2), pp. 282-307.

Atienza, M.E. (2000). Gender and local governance in the Philippines'. In: R.J. Lee and C. Clark, ed., Democracy and the Status of Women in East Asia, Colarado: Lynne Rienner Publishers.

Bradley, M.S. (2007). Girlfriends, wives, and strippers: Managing stigma in exotic dancer romantic relationships. Deviant Behavior, 28, pp. 379-406.

Dewa D. et al. (2013). Industrial decline in Zimbabwe, Gweru post 414 2000: which way now? World Journal of Arts, Commerce and Sciences, 1(1), pp. 1-13.

Edlund and Korn (2002). A Theory of Prostitution. Journal of Political Economy, 110(1), pp. 282-296.

Goffman, E. (2004). Stigma- Notes on the Management of Spoiled Identity. New York: Simon and Schuster/Touchstone Books.

Haleh, A. (2003). Women in Conflict, Post-Conflict and Reconstruction. Carfax: Basingstoke.

Hawe, P. and Shiell, A. (2000). Social Capital and Health Promotion: A Review. Social Science and Medicine, 51, pp. 871-885.

Howe, R.K. (2014). The Stigma: The Collective Struggle and Right to Sexual Self-determination among Commercial Sex Workers in two Locations in Trinidad. Journal of the Department of Behavioural Sciences, 3(1), pp. 14-17.

Hubbard and Sanders (2003). Making space for sex work: Female street prostitution and the production of urban space. International Journal of Urban and Regional research, 27(1), pp. 75-89.

Jackson, L.A., Bennett, C.G. and Sowinski, B.A. (2007). Stress in the sex trade and beyond: Women working in the sex trade talk about the emotional stressors in their working and home lives. Critical Public Health, 17(3), pp. 257-271.

Kong, T.S.K. (2006). What it feels like for a whore: The body politics of women performing erotic labour in Hong Kong. Gender, Work and Organization, 13(5), pp. 409-434.

Lesley, A. (2000). From pal tree to parliament: Training women for political leadership and public life, Gender \& Development, 8(3), 172.

Mukhopadhyay, M. (2004). Introduction. In: Gender, Citizenship and Governance, A Global source Book, Netherlands, OXFAM GB: Royal tropical Institute.

Thomas, S. (2015). About Social Capital. Saguaro Seminar: Civic Engagement in America. John F. Kennedy School of Government at Harvard University.

Thomson, W.E., Harred, J.L. and Burks, B.E. (2003). Managing the stigma of topless dancing: A decade later. Deviant Behavior, 24(6), pp. 551-571.

Tomura, M. (2009). A Prostitute's Lived Experiences of Stigma. Journal of Phenomenological Psychology, 40, pp. 51-84.

Sarkin, A.J. et al. (2011). Evaluating a Measure of Social Health Derived from Two Mental Health Recovery Measures: The California Quality of Life (CA-QOL) and Mental Health Statistics Improvement Program Consumer Survey (MHSIP), Community Mental Health Journal, 47(4), pp. 454-462.

Vanwesenbeeck, I. (2005). Burnout among female indoor sex workers. Archives of Sexual Behavior, 34(6), pp. 627639.

Wong W.C., Holroyd, E. and Bingham, A. (2011). Stigma and sex work from the perspective of female sex workers in Hong Kong, Social Health and Illness, 33(1), pp. 50-65.

World Health Organization (1980). International Classification of Impairments, Disabilities, and Handicaps. Geneva: Author. 